\title{
INVESTIGATION OF THE EFFECT OF DEPTH OF CUT AND CUTTING SPEED ON CUTTING FORCES DURING FACE MILLING OF STEEL WITH A RECTANGULAR CUTTING INSERT
}

\begin{abstract}
In metal machining processes, the achievement of a sufficiently high material removal rate is desirable. Material removal rate can be increased to the desired value by an increase of feed rate value and also by increase of cutting speed or depth of cut values. However, as it is also required that surface quality and deformation should be within the acceptable limits, it is necessary to control them by selecting the appropriate process parameters values. In this study, face milling experiments are conducted in order to investigate the effect of using different values of depth of cut and cutting speed on the cutting forces and specific cutting forces. A comparison between the experimental results from cases with constant feed rate and two different depths of cut at four different cutting speed values, ranging from 100 to $400 \mathrm{~m} / \mathrm{min}$ is conducted. After the subsequent analysis of the results, conclusions on the effect of depth of cut and cutting speed on cutting forces and specific cutting forces are drawn.

Keywords: face milling; cutting forces; depth of cut; cutting speed; rectangular inserts.
\end{abstract}

\section{INTRODUCTION}

Machining processes are always of great importance when fabrication of metallic parts with high surface quality and integrity and high dimensional and geometric accuracy is required. At the same time, the achievement of the aforementioned goals should be consistent with the achievement of high efficiency of the material cutting process. Especially, by employing face milling, it is possible to produce flat surfaces of excellent quality as well as to achieve acceptable surface integrity.

In the previous works of our scientific team [1-3], experiments were conducted in order to determine the dependence of face milling outcome, namely cutting forces and surface roughness, on the variation of feed rate. Thus, in the present work it is desired to analyze the effect of different depths of cut and cutting speeds to the cutting forces and specific cutting forces during face milling.

Regarding cutting speed, it is almost undisputable that it has an inverse effect on cutting forces; thus, an increase of cutting speed leads to a decrease of cutting forces. This decrease can be observed in all force components and especially in $\mathrm{F}_{\mathrm{x}}$ and $\mathrm{F}_{\mathrm{y}}$ components $[4,5]$ and occurs in both up and down milling cutting modes [5]. Furthermore, this trend is shown to exist even at large speeds, up to $3000 \mathrm{~m} / \mathrm{min}[5,6]$.

(C) N.E. Karkalos, A.P. Markopoulos, T. Makkai, J. Kundrák, 2019

However, opinions are divided on whether the effect of cutting speed on cutting forces is significant or not with most researchers stating that it is lower than the effect of feed rate or depth of cut [7-9].

The decrease of cutting forces with increase of cutting speed is attributed either to the increase of temperature which leads to workpiece material softening [5] or to the lower tendency of built-up edge generation at high speeds, something that leads to more stable cutting [10]. This decrease of cutting forces is mostly reported to be almost linear $[6,11,12]$ with some researchers reporting non-constant decrease rate [7].

Regarding depth of cut, it is shown, in every case, that its increase leads to an increase in cutting forces. As with cutting speed, its effect is more profound in $\mathrm{F}_{\mathrm{x}}$ and $\mathrm{F}_{\mathrm{y}}$ components whereas $\mathrm{F}_{\mathrm{z}}$ is the least affected force component [4]. Furthermore, this effect can be undoubtedly observed in both symmetric and asymmetric milling [9]. Most researchers state that the depth of cut has a significant effect on cutting forces, along with feed rate [8-10]. The increase of cutting forces with an increase of depth of cut is attributed to an increase of tool-workpiece contact length [5] and the increase of cross-sectional area of uncut chip [4]. This increase is found, at least partially, non-linear, especially at higher depths of cut $[6,11,12]$.

\section{EXPERIMENTAL CONDITIONS}

In the present work, face milling experiments with a milling head having a single cutting insert were performed in steel workpieces. The aim of the research is to determine quantitatively the effect and relative importance of depth of cut and cutting speed on cutting forces and specific cutting forces during face milling, determining also the variation of the increasing or decreasing trend of cutting forces due to variation of these parameters. In particular, the investigation of process parameters effect on specific cutting forces is rarely conducted in the relevant literature and thus, it will be of significant interest.

All the experiments were conducted on a PerfectJet MCV-M8 vertical machining center. The details concerning the cutting insert and milling head are presented in Table 1, along with the process parameters values.

Experiments with a constant feed rate of $0.4 \mathrm{~mm} /$ tooth, two different cutting depth values, namely 0.4 and $0.8 \mathrm{~mm}$ and four different cutting speed values in the range of 100 to $400 \mathrm{~m} / \mathrm{min}$ are conducted. All the experiments are performed under dry machining conditions. During the experiments, the three components of force, namely $F_{x}, F_{y}, F_{z}$ were measured in a coordinate system relative to the workpiece by a Kistler 9257A dynamometer. The measured signal was amplified using three Kistler 5011A charge amplifiers. The data were sent to a PC using a Compact DAQ-9171 data collector by National Instruments Company and finally the data were recorded on the PC using software prepared in the LabView programming language.

Table - Experimental conditions 


\begin{tabular}{|l|l|l|}
\hline Cutting insert & $\begin{array}{l}\text { Sandvik R215.44-15T308M-WL GC4030 coated carbide } \\
\text { insert }\left(\kappa_{\mathrm{r}}=90^{\circ} ; \gamma_{\mathrm{o}}=0^{\circ} ; \alpha_{\mathrm{o}}=11^{\circ} ; \mathrm{r}_{\varepsilon}=0.8 \mathrm{~mm}\right)\end{array}$ \\
\hline Milling head type & $\begin{array}{l}\text { Sandvik R252.44-080027-15M face milling head } \\
\left(\mathrm{D}_{\mathrm{s}}=80 \mathrm{~mm}\right)\end{array}$ \\
\hline Workpiece material & Normalized C45 (1.0503) carbon steel $(\mathrm{HB}=180)$ & \\
\hline Workpiece dimensions & Width: $58 \mathrm{~mm}$, Length: $50 \mathrm{~mm}$ \\
\hline Cutting speed $\mathrm{v}_{\mathrm{c}}[\mathrm{m} / \mathrm{min}]$ & $100,200,300,400$ \\
\hline Depth of cut $\mathrm{a}_{\mathrm{p}}[\mathrm{mm}]$ & $0.4,0.8$ \\
\hline Feed rate $\mathrm{f}_{\mathrm{z}}[\mathrm{mm} /$ tooth $]$ & 0.4 & \\
\hline
\end{tabular}

\section{EXPERIMENTAL RESULTS AND DISCUSSION}

After the experiments were carried out, analysis of the obtained results was conducted. For each experiment, force diagrams were processed in order to determine the maximum values for each force component, namely $F_{x}, F_{y}$ and $F_{z}$. For each component of forces, for all depths of cut and cutting speeds, the obtained maximum force values are depicted in Figure 1.

From the results presented in the left column of Figure 1, it can be clearly observed that an increase in cutting speed leads to a decrease of cutting forces in most cases and an increase of depth of cut results in an increase of cutting forces, as it was anticipated. Furthermore, $\mathrm{F}_{\mathrm{y}}$ component is shown to have larger values than the other two force components. These results are consistent with results reported in the relevant literature [4, 5, 7]. Moreover, the calculation of ratio of change of forces between cases with different depth of cut values was conducted by using the following formula:

$$
\text { ratio of change }=\left|\frac{F_{a_{p=0.8}}}{F_{a p=0.4}}\right|
$$

From the observed trends, it was revealed that the difference between force values at different depths of cut has an increasing trend for $F_{x}$ and $F_{y}$ components, whereas in the case of $F_{z}$ component, it is almost constant. For $F_{x}$ and $F_{y}$ a change between $a_{p}=0.4 \mathrm{~mm}$ and $0.8 \mathrm{~mm}$ results in 1.5 to 2 times increase in cutting force value whereas, for $F_{z}$ the increase is almost 1.25 times. Among the three force components, $F_{x}$ was found to be more significantly affected by the variation of depth of cut, a conclusion that can be observed by the largest slope of the regression trend line in that case.
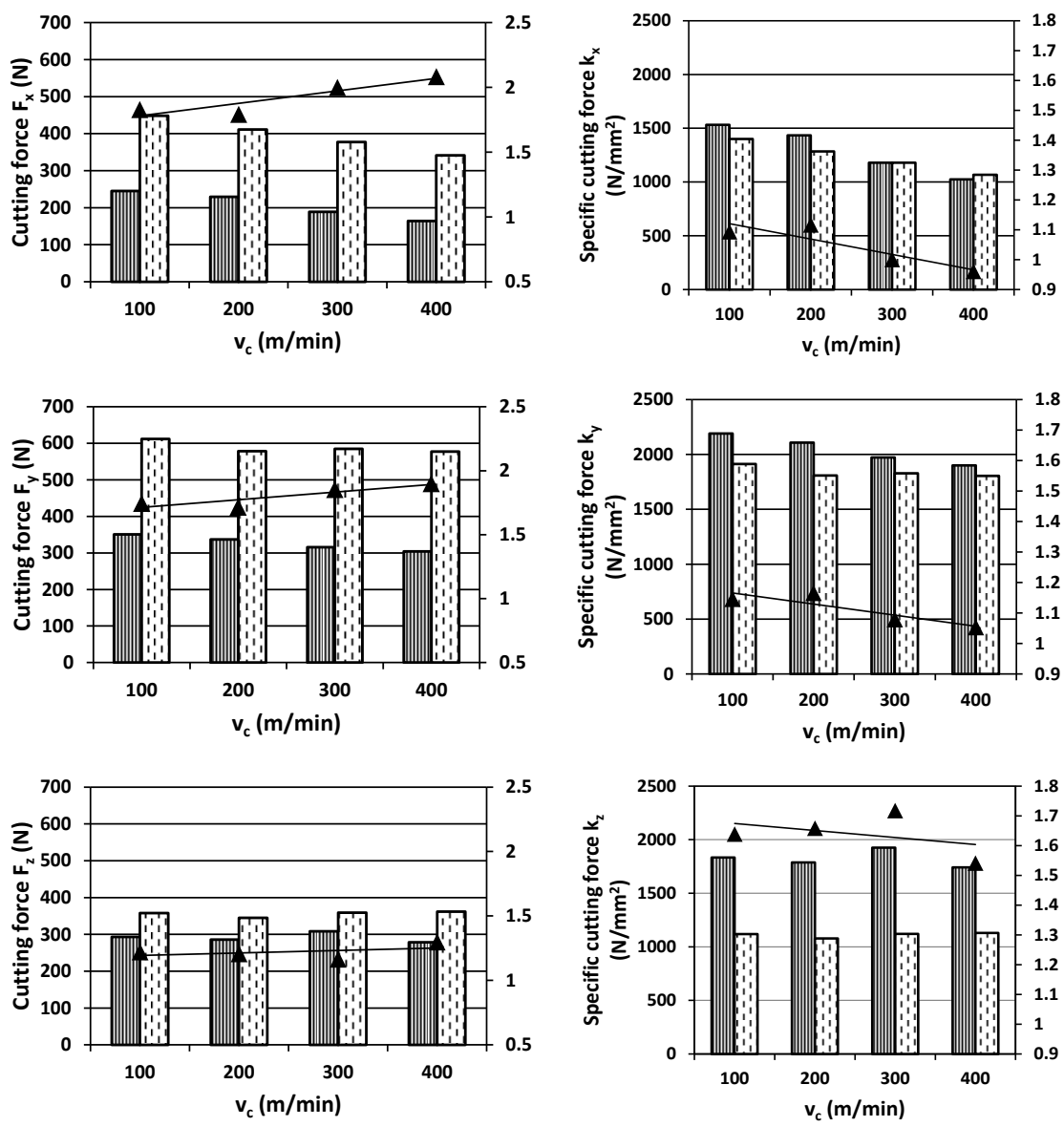

an $=0.4 \mathrm{~mm}$

एт.

atio of change - trendline

Figure 1 - Cutting force (left column) and specific cutting force (right column) components values for cases with different depths of cut and cutting speeds 
Regarding the cutting speed, the ratio of change of force values for cases between 100 and $400 \mathrm{~m} / \mathrm{min}$ was also calculated for both values of depth of cut, as the ratio of cutting force component value at $100 \mathrm{~m} / \mathrm{min}$ divided by the cutting force component value at $400 \mathrm{~m} / \mathrm{min}$. It was found that, for $F_{x}, F_{y}$ and $F_{z}$ components of force, the ratio of change of forces between the cases at 100 and $400 \mathrm{~m} / \mathrm{min}$ was $1.49,1.15$ and 1.05 , respectively at $\mathrm{a}_{\mathrm{p}}=0.4 \mathrm{~mm}$ and 1.31 , 1.06 and 0.98 , respectively at $\mathrm{a}_{\mathrm{p}}=0.8 \mathrm{~mm}$.

Thus, it can be attested that, $F_{x}$ component was the most affected by the variation of cutting speed, $F_{z}$ component was almost unaffected and the impact of cutting speed on cutting forces was more significant at the lowest value of depth of cut.

Finally, if the effect of depth of cut on cutting forces is compared to that of cutting speed, it is shown that for a 2 fold increase of depth of cut, the variation of cutting forces is larger than for a 4-fold increase of cutting speed; thus, it is revealed that the depth of cut has a more significant effect on cutting forces.

After the effect of depth of cut and cutting speed on cutting forces was determined, it was considered important to determine the effect of depth of cut and cutting speed on specific cutting forces as well. Specific cutting forces are calculated as the ratio of cutting forces components to the chip cross-section value $\left(\mathrm{A}_{\mathrm{c}}\right)$ and are closely related to the loading on the cutting insert [1]. For each cutting force component, the relevant specific cutting force component is denoted as $\mathrm{k}_{\mathrm{i}}$ where $\mathrm{i}=\mathrm{x}$ or $\mathrm{y}$ or $\mathrm{z}$.

From the results presented in the right column of Figure 1, it can be seen that an increase of cutting speed results in a decrease of specific cutting forces in most cases, especially for $\mathrm{k}_{\mathrm{x}}$ and $\mathrm{k}_{\mathrm{y}}$ components and an increase of depth of cut leads also to a decrease of specific cutting forces. Similarly with the case of cutting forces, the $\mathrm{k}_{\mathrm{y}}$ component is largest between the three components of specific cutting forces.

From the calculated values of ratio of change of specific cutting forces between cases with different depths of cut, it can be seen that for all three specific cutting force components, there is a decreasing trend with an increase of cutting speed. The largest values for the ratio of change are observed for $\mathrm{k}_{\mathrm{z}}$, which is decreased almost 1.5 times with an increase of depth of cut, whereas the lowest values are observed for $\mathrm{k}_{\mathrm{x}}$. Regarding the cutting speed, the ratio of change of specific cutting forces between cases with cutting speed of $100 \mathrm{~m} / \mathrm{min}$ and $400 \mathrm{~m} / \mathrm{min}$ is also calculated. It was found that, for $\mathrm{k}_{\mathrm{x}}, \mathrm{k}_{\mathrm{y}}$ and $\mathrm{k}_{\mathrm{z}}$ components of specific cutting force, the ratio of change of specific cutting forces between the cases at $100 \mathrm{~m} / \mathrm{min}$ and $400 \mathrm{~m} / \mathrm{min}$ was $1.49,1.15$ and 1.05 , respectively at $\mathrm{a}_{\mathrm{p}}=0.4 \mathrm{~mm}$ and $1.31,1.06$ and 0.99 , respectively at $\mathrm{a}_{\mathrm{p}}=0.8 \mathrm{~mm}$. Thus, $\mathrm{k}_{\mathrm{x}}$ was more affected from the change in cutting speed whereas the other two components of specific cutting forces were less affected by this change, especially at $\mathrm{a}_{\mathrm{p}}=0.8 \mathrm{~mm}$.

Thus, in the case of specific cutting forces, it was observed that the variation of cutting speed was less important than the variation of depth of cut, but in this case the difference in the effect of these two parameters was lower than the difference observed in the case of cutting forces.

\section{SUMMARY}

Milling experiments were performed by rectangular inserts with the aim of studying the change of cutting forces and specific cutting forces as function of cutting speed.

All of the three components of cutting force increased, as the depth of cut also increased from $0.4 \mathrm{~mm}$ to $0.8 \mathrm{~mm}$. $F_{z}$ was less affected, while $F_{x}$ and $F_{y}$ increased equally, approximately to their double. The magnitude of the increase was higher for cutting speed $v_{c}$. The values of the specific cutting forces $k_{x}$ and $k_{y}$ decreased by the increase of cutting speed. Such a tendency cannot be observed in the values of $\mathrm{k}_{\mathrm{z}}$. The values of $\mathrm{k}_{\mathrm{x}}$ and $\mathrm{k}_{\mathrm{y}}$ are about the same at the two depths of cut, while the values of $\mathrm{k}_{\mathrm{z}}$ decrease significantly, namely 1.5 to 1.7 -fold.

This means that the cutting force $F_{c}$, acting on the insert, changes proportionally with the change of depth of cut, and this ratio is maintained with the different cutting speeds, too, while the change of cutting speed practically does not affect its value.

\section{ACKNOWLEDGEMENTS}

The authors greatly appreciate the support of the National Research, Development and Innovation Office - NKFIH (No. of Agreement: K 116876).

The described study was carried out as part of the EFOP-3.6.1-16-00011 "Younger and Renewing University Innovative Knowledge City - institutional development of the University of Miskolc aiming at intelligent specialization" project implemented in the framework of the Szechenyi 2020 program.

Both supports are gratefully acknowledged.

References: 1. Kundrák, J., Markopoulos, A.P., Makkai, T., Deszpoth, I., Nagy, A.: Analysis of the effect of feed on chip size ratio and cutting forces in face milling for various cutting speeds, Manufacturing Technology 18(3), pp. 431-438. (2018). 2. Kundrák, J., Makkai, T., Markopoulos, A.P.: Investigating the impact of feed and cutting speed on cutting forces for the increase of surface removal rate in face milling, Cutting \& Tools in Technological Systems: NTU 'KhPI' 87, pp.126-132. (2017). 3. Kundrák, J., Makkai, T., Deszpoth, I., Nagy, A.: Investigation of cutting force in face milling, Cutting \& Tools in Technological Systems: NTU 'KhPI' 87, pp.118-125. (2017). 4. Subramanian, M., Sakthivel, M., Sooryprakash, K., Sudharakan, R.: Optimization of cutting parameters for cutting force in shoulder milling of Al7075-T6 using response surface methodology and genetic algorithm, Procedia Engineering 64, pp. 690-700. (2013). 5. Čekić, A., Begić-Hajdarević, Đ., Kulenović, M.: Effect of the cutting parameters on cutting forces in high speed face milling, Tehnički Vjesnik 20(5), pp.775-780. (2013). 6. Ghoreishi, R., Roohi, A.H., Ghadikolaei, A.D.: Analysis of the influence of cutting parameters on surface roughness and cutting forces in high speed face milling of Al/SiC MMC, Materials Research Express 5(8), 086521. (2018). 7. Kaya, E., Akyüz, B.: Effects of cutting parameters on machinability characteristics of Ni-based superalloys: a review, Open Engineering 7, pp. 330-342. (2017). 8. Ghani, J.A., Choudhury, I.A., Hasan, H.H.: Application of Taguchi method in the optimization of end milling parameters, Journal of Materials Processing Technology 145, pp. 84-92. (2004). 9. Aykut, Ş., Kentli, A., Gülmez, S., Yazıcıoğlu, O.: Robust multiobjective optimization of cutting parameters in face milling, Acta Polytechnica Hungarica 9(4), pp. 85-100. (2012). 10. Xu, C., Dou, J., Yuzhen, C., Huaiyuan, L., Zhicheng, S., Jing, X.: The relationships between cutting parameters, tool wear, cutting force and vibration, Advances in Mechanical Engineering $10(1)$ 
11. Pathak, B.N., Sahoo, K.L., Mishra, M.: Effect of machining parameters on Cutting forces and surface roughness in Al-(1-2)Fe-1V-1Si Alloys, Materials and Manufacturing Processes 28(4), pp. 463-469. (2013). 12. Subramanian, A.V.M., Nachimuthu, M.D.G, Cinnasamy, V.: Assessment of cutting force and surface roughness in $\mathrm{LM6} / \mathrm{SiC}_{\mathrm{p}}$ using response surface methodology, Journal of Applied Research and Technology 15, pp. 283-296. (2017).

Ніколаос Е. Каркалос, Ангелос Р. Маркопулос, Афіни, Греція,

Тамаш Маккаі, Янош Кундрак, Мішкольц, Угорщина

\section{ДОСЛІДЖЕННЯ ВПЛИВУ ГЛИБИНИ РІЗАННЯ І ШВИДКОСТІ РІЗАННЯ НА СИЛИ РІЗАННЯ ПРИ ТОРЦЕВОМУ ФРЕЗЕРУВАННІ СТАЛІ ФРЕЗАМИ З ПРЯМОКУТНИМИ РІЖУЧИМИ ПЛАСТИНАМИ}

Анотація. У процесах механічної обробки металу бажсано досягнення досить високої швидкості видалення матеріалу. Швидкість видалення матеріалу може бути збільшена до бажаного значення иляхом збільшення значення швидкості подачі, а також иляхом збільшення швидкості різання або глибини різання. Однак, оскільки також вимагається, шоб якість поверхні $і$ деформація перебували в допустимих межах, необхідно контролювати їх, вибираючи відповідні значення параметрів процесу. У изьому дослідженні проводяться експерименти по ториевому фрезеруванні з метою вивчення впливу використання різних значень глибини різання $і$ швидкості різання на сили різання і питомі сили різання. Проведено порівняння експериментальних результатів для випадків з постійною швидкістю подачі $і$ двома різними глибинами різання при чотирьох різних значеннях швидкості різання. Після подальшого аналізу результатів робляться висновки про вплив глибини різання і швидкості різання на сили різання і питомі сили різання. Експерименти з фрезерування проводилися за допомогою фрез, оснащених прямокутними пластинами з метою вивчення зміни сил різання $і$ питомих сил різання в залежності від швидкості різання. Всі три складові сили різання збільшилися, з ростом значення глибини різання. Тангенціальна складова змінилася менше, в той час як осьова і нормальна збільшилися однаково, приблизно в два рази. Величина збільшення була вище зі зміною швидкості різання. Значення питомих сил різання нормальної і осьової зменшувалися зі збільшенням швидкості різання. Така тенденція не спостерігається в значеннях питомої тангенціальної сили. Значення нормальної і осьової питомої сили різання приблизно однакові на двох глибинах різання, тоді як значення тангенціальної значно зменшуються, а саме в півтора рази. Це означає, щзо сила різання, цчо діє на пластину, змінюється пропориійно зміні глибини різання, і ие співвідношення підтримується і при різних швидкостях різання, в той час як зміна швидкості різання практично не впливає на ї̈ значення.

Ключові слова: торцеве фрезерування; сили різання; глибина різання; ивидкість різання; прямокутні вставки. 
